\title{
Translating Her Story: A Woman in Quest of a Language
}

Meena T. Pillai

\begin{abstract}
Madhavikutti's Ente Katha is an autobiography of a woman who opted to write rather than die. Thus writing becomes an act of self-inscription in a language and culture that tries to silence her sexuality. Ente Katha, by valorizing the female body created a furore in Kerala society in the seventies. For the first time a woman used the Malayalam language blatantly, throwing to the winds a culture's preoccupations and values, in the process critiquing all its dominant discourses. Her potentially subversive act of invoking the semiotic in the Malayalam language and literature paved the way for writing the female body in a way radically different from male writings in terms of linguistic structure and content. But when Madhavikutty translated her story as Kamala Das's My Story in English, she must have encountered serious problems transcreating the female body written into the source language. The strategies by which the category 'Malayalee woman', her multiple subject positions in Ente Katha and the cultural contingency of her experiences of oppression, get translated into the linguistic, historical and cultural specificities of a language such as English, form the scope of this paper. It is an attempt to analyse the process of translation by which the discursively constructed 'Madhavi kutty' of
\end{abstract}

Translation Today Vol. 2 No. 2 Oct. 2005 @ CIIL 2005 
Ente Katha translates herself into the 'Kamala Das' of My Story.

An autobiography is considered a genre of literature where the umbilical cord between the story and the reality, the writer and the text, the signifier and the signified is yet intact. Kamala Das is one of the few writers in India who could snip this cord with élan, explicating in the process that all writings are constructed and all realities staged in language.

My Story is not a literal translation of Ente Katha, which was originally serialized in the Malayalam magazine Malayalanadu in 1972. And yet the title Ente Katha translates as My Story. Kamala Das later famously denied Ente Katha to be a true story stating that parts of it were fictitious. So whose is the voice that narrates Ente Katha/My Story? By positing this self as a fictional construct, by problematising it, Kamala Das actually poses a problem of identity, a problem linked to language, of writing one self in two languages, in the process attempting to evolve a third - a language for writing the woman into existence. By celebrating the functionality of her autobiography Das reiterates modern theories on the genre which stress the "tautological nature of autobiography" pointing out that the "autobiographical self is a fictional construct within the text which can neither have its origins anterior to the text nor indeed coalesce with its creator."

James Olney speaks of how it is impossible for an autobiographer to write the image double of her life instead having to create herself afresh at every moment within the text. This might be the reason why Das chose not to go for a literal translation of Ente Katha into English but a creative retelling aiming towards textual equivalence. This is what she has to say in an interview

"I have certain firm views about translation, I don't go in far a word-to-word translation. I always try to retain the spirit of the 
original in translation.... But I find it difficult to translate people who do not give me the freedom to reconstruct the work because without adding a little or subtracting a few lines I wouldn't be able to manage. I wouldn't be able to make it a finished work because I find in most regional literature certain inadequacies that come with the writer being a little bit too pompous to be a success. Because there are posturings which do not appeal to me. I would like a writer to be as honest as he or she can be."

It is possible to speculate from textual evidence that $M y$ Story or parts of it were written first, which then formed the base for the translated/adapted/retold Ente Katha. The editor of Malayalanadu, VBC Nair, in an interview reminisces about Kakkanadan's translation of the first chapter of Ente Katha from English. Madhavikutty herself says, "I dream in English, I am afraid." If this be the case, the very act of writing Ente Katha becomes an act of translating the self from the source language of English, to the target language of Malayalam, a reclaiming and recentering of identities in a new linguistic and cultural territory.

Chapter 2 of Ente Katha begins thus:

"Yesterday evening in our visitor's room my husband told the Marathi poet Purushotham Rege, 'Kamala has started writing her autobiography'. He asked me to bring the first chapter and read it aloud to Rege. I did not comply with his request. I felt it would be like taking out a one-month-old embryo from the womb and exhibiting it. I never show my poems or stories to anyone before their publication." (p.18)

The first chapter of Ente Katha reads as follows:

"When my friends came to know that I have started writing pieces of my autobiography, some of them said that no one less than forty years of age should attempt to write an autobiography" (p.13). 
It is significant that no such references to the writing of an autobiography come up in My Story. That Kamala Das had started writing her autobiography and her friends know about it contradict the popular belief that it was a story written by a woman on her deathbed. Though this could be partly true, yet the textual evidences suggest that Kamala Das had started writing her story much before she reached the hospital bed and formed a contract with the editor of Malayalanadu to serialize Ente Katha. So it raises the question of which is the original text and problematises the notion of fidelity to the 'original'.

In My Story Das narrates her early education at home at the age of six,

\begin{abstract}
"We had two tutors: Mabel, a pretty Anglo-Indian, and Nambiar, the Malayalam tutor. The cook was partial to the lady; served her tea on a tray... to Nambiar who came much later in the evening he gave only a glasstumbler of tea and a few sardonic remarks. Nambiar in our house moved about with a heavy inferiority complex and would hide behind the sideboard when my father passed through the dining room where we had our Malayalam lessons. We learned our vernacular only to be able to correspond with our grandmother who was very fond of us." (p.9)
\end{abstract}

But in Ente Katha she is only four when the two tutors come to teach the children. The Anglo Indian Mabel becomes the Mangalorean Mrs. Sequeira. The Nambiar of My Story who received only tea and sardonic remarks is fortunate enough to receive 'Parippu Vada' with his tea in Ente Katha. And yet it is Nambiar's inferiority complex in My Story that is attributed to the Malayalam language in Ente Katha. Madhavikutty writes, "In those days we felt that Malayalam Language had Nambiar's colour and his inferiority complex" (p.16). 
As Foucault argues "all manifest discourse is secretly based on the 'already said'; ... this 'already-said' is not merely a phrase that has already been spoken, or a text that has already been written, but a 'never-said', an incorporeal discourse, a voice as silent as a breath that is merely the hollow of its own mark." It can be argued that My Story is the as yet incorporeal discourse, the silent breath that permeates Ente Katha. The consciousness of an 'I' that performs/lives its gender in Ente Katha has an altogether different angle of entrance - that of an English language and education. The inferiority complex, which marks the learning of the vernacular, is first attributed to the tutor in the English version and then to the language itself in the Malayalam version in what I argue to be a gradual systematization of concepts, knowledge and experience in language.

Ente Katha displays more difficulties of narrating the self because Malayalam provides a cultural frame of reference within which the story is situated. In English the frame of reference is removed spatially and culturally and hence the emotional problems associated with remembering and narrating is lesser. For a woman the weight of patriarchal ideology is more intense and excruciating in her own native language than in English. Hence telling the story is easier in English where value systems, cultural concepts and social norms that model experience are different. As language changes the ideological contexts too change, the process of processing memory changes, and techniques of cognitive mapping change. That Ente Katha is significantly less in volume than My Story reveals the ideological problem of narrating a woman's story in Malayalam where the acts of remembering and reiterating have painful emotional overtones. Thus the methodology of remembering the past is weighed down by a political and cultural load in Ente Katha, while in My Story the process is easier.

The English version of the autobiography has afforded Kamala Das the neutrality, whereas the Malayalam version carries 
the weight of markers of native codes like religion, ethnicity and gender. My Story is a good example of cultural code-mixing where English is used "to neutralise identities one is reluctant to express by the use of native languages or dialects."

My Story skillfully uses the English language to provide referential meaning while escaping Malayalam's cultural overtones and connotations, thus helping in the process of an identity shift obscuring the Madhavikutty, culturally conditioned by the Kerala society and discursively constructed as 'a Malayalee woman', in order to foreground the culturally neutral, more universal identity of Kamala Das. Thus Kamala Das's transcreation of her story skillfully uses the English tongue to manipulate and control the normative and regulatory codes of Malayalam. The values and norms of English have been used to nullify traditional hierarchies of caste, class and gender. Thus in My Story the cultural power base of Ente Katha is mitigated to a certain extent. English's "power of alchemy linguistically to transmute an individual and a speech community" is what becomes evident in My Story where English transmutes the 'self' by providing more modernized registers to write the woman in.

In conjunction with the argument that language and social models greatly influence the narrativisation of the self, this paper seeks to illustrate how linguistic and semantic processes, linked to social models affect the construction of gender identity in such a way that the same identity might be projected differently while narrating the same life story in two different languages. By using the possessive pronoun My/Ente, Kamala Das/Madhavikutty fuses the author, narrator and character into one self. By denoting it as Story/Katha the writer consciously or unconsciously veers more towards a similar genre of the 'life-story' than autobiography per se. Though both genres are the product of a process of narrativisation, fictionalization and textualisation, "the life story develops specific traits; the orality of the genre produces a system of formal and structural recurrences and the interactional system as well as the 
stress on the social self, produce reference to socio-symbolic discourse and the social imaginary through which a culture by means of language, maps and deciphers the world, a dimension also present in autobiography, but heavily marked in the life-stories."

In the life story, unlike in an autobiography, the author/narrator presumes an interaction with an audience, an audience that shares her models of experience and codes of culture. Though Kamala Das arranges all the important rites of passage charting the course of the evolution of the self and narrates all the events according to a chronological and causal scheme in My Story, Ente Katha displays certain reluctance to the usual patterns of constructing the life story. It is more complex in its narration. The linear, confessional mode of narrative in My Story links it to a modernist form of writing while Ente Katha displays postmodern preoccupations in its part non-linear narrative relying on what appears to be a more disjointed memory. The preface to Ente Katha titled 'A Sparrow's Sorrow' is absent in My Story, and it is in this introduction to her life that Madhavikutty attempts to subtly negotiate the social contract in the act of writing one's story in the Kerala society of the early seventies. She writes in Ente Katha

"Though I loved my husband deeply, he was unable to love me. At the moment of sexual intercourse with him I wished he would gather me in his arms after the act. Had he caressed my face or touched my belly I would not have felt to that degree the intense rejection I felt after each sexual union. When a woman relinquishes the first man in her life in order to walk up to the bed of another, it is not a contemptuous or immoral act; it is an act of pathos. She is one who is humiliated, wounded. She needs to quench herself' (p.8).

In subverting the conventions of a woman's autobiography Kamala Das shows how a woman constructed in accordance with the rigid codes of expectations of femininity can yet deconstruct herself in order to reveal the constructedness of her self. The one page 
preface to My Story is stretched to nearly six pages in Ente Katha, a rather strenuous exercise considering the fact that the Malayalam version as a whole is much shorter than the English one. Madhavikutty in the preface to Ente Katha takes great pains to place her narrative identity inside the world of textual conventions and yet outside it. More of a testimony than a confession, Madhavikutty here seems to address a culture whose expectations of conformity to an ideal of the feminine she cannot cater to. In contrast the preface to My Story ends thus, "This book has cost me many things I hold dear, but I do not for a moment regret having written it. I have written several books in my lifetime but none of them provided the pleasure the writing of My Story has given me. I have nothing more to say." It is significant that this preface is found only in the Sterling edition published from New Delhi in 1976. The DC Books edition published from Kerala in 2004 omits this preface. The preface to Ente Katha begins thus,

"A few years ago, one day in the afternoon, a sparrow flew into my room through the small window. Its breast hit the turning blades of the fan and the bird was thrown down. Hitting the windowpane, it clung to the glass for a few seconds. The blood from its breast stained the glass. Today let my blood ooze down to these pages let me write in that blood. Let me write without the burden of a future, as only one can write, making each word a compromise. I would love to call this poetry... I always wished I had the strength to write this. But poetry never ripens for us; we have to acquire the maturity for it" (p.7). Here Madhavikutty is seen to renegotiate Kamala Das's relationship to the act of writing. The last sentence seems to emphasize that society needs to change in order to accept her writing. She turns the tables on societal norms and yet the pressures of conformity catch up with her as is evident in her many denials later on to the veracity of Ente Katha.

The self that is outwardly projected in My Story/Ente Katha is a self that tries to fit in, to conform, at least on the surface. This 
self is seen to situate and organize society and culture. Yet there is a progress towards a self that attains boldness in negotiating its relationship with the external world. What is achieved in the end is a new sense of identity, a woman who discovers her sexuality and who learns to revel in her multiple selves. But even here there is a difference in the two texts. My Story is more unapologetic and direct in its narration while Ente Katha is informed by a sense of 'inter subjectivity'- a consciousness of the self as framed and limited by its interactions with the symbolic order. Wariness towards the audit culture is omnipresent in Ente Katha. Probably Madhavikutty is more conscious in her negotiations with the culture of the Malayalam language and its literary repertoire, knowing fully well that there are greater issues at stake in the autobiography's encounter with the social order here than in English. A mere look at the chapter headings will illustrate this point. The Sterling edition of My Story has fifty chapters some of which are titled - 'I was infatuated with his charm', 'Women of good Nair families never mentioned sex', 'Was every married adult a clown in bed, a circus performer?', 'Her voice was strange, it was easy for me to fall in love with her', 'His hands bruised my body and left blue and red marks on the skin', 'Sex and the co-operative movement', 'I too tried adultery for a while', 'I was never a nymphomaniac' etc. Again, strikingly, all these headers are changed in the 2004 DC edition of My Story. For example, 'I was infatuated with his charm' is changed into the innocuous title 'The village school', while 'Women of good Nair families never mentioned sex' becomes 'The Feudal System'. None of the original titles find place in the Malayalam version which has chaste headers like 'The meaning of the word love', 'The season called beauty', 'Morality and rebirth,' etc. Thus here we have a writer/translator beset by different levels of cultural intervention while writing/translating in two different languages. Even the year and place of publication assume important dimensions. A female identity constituted by an intense awareness of sexuality is seen to be narrated, however subversively, with an acute awareness of the policing medium of culture which a language represents. Thus the 
expectations of conformity to a feminine cultural ideal is more on Madhavikutty than on Kamala Das, and hence disguises and ambiguities at the structural and narrational level of the text is more in Ente Katha than My Story. This leads to a situation where what is written has not been translated and what is translated has not been written. Madhavikutty's cultural identity often acts as a block in Ente Katha, forcing her to take more circuitous routes of narration. For example the first meeting with her would be husband, his sexual advances, their engagement, the subsequent visit to Calcutta, his crude attempts at sexual games, are all described in a simple, chronological straight forward manner in My Story. But in Ente Katha these incidents are compressed into two pages with philosophic ruminations and forward jumps in time. In all parts of the narrative where gender roles are crucial Ente Katha displays a marked transferential tension at play, which is not so evident in $M y$ Story. For example in the description of the rape where the old maid servant plays accomplice to the rapist, the whole incident is left ambiguous in Ente Katha, leaving the reader doubting the veracity of the incident. In My Story however, the narration leaves no doubt about the reality of the incident. "The autobiographical tongue in any bilingual context is unlikely to tell the kind of homogenous and singular truth which critics of autobiography, quite contradictorily, seem both to disdain and desire." The process of historicizing the subject and illustrating her dependence on the social order is more in evidence in Ente Katha, which offers innovative possibilities as far as the question of the specificity of women's writing leading to a feminist narratology is concerned.

Born in rural Kerala, brought up and schooled in Calcutta, married to a bank officer in Mumbai, spending a life divided among the cosmopolitan cities of Calcutta, Mumbai and Delhi, Kamala Das alias Madhavikutty projects a translated self living in translated worlds. An intellectual self fashioned in the English tradition, yet bearing the weight of Malayalam's linguistic and cultural history, her autobiography is both writing to and translating from the 
language of patriarchy. Probably it is this translatedness of being that helped Kamala Das to challenge the authoritive codes of languages and cultures. Translation here could be a metaphor for any activity in language that destabilises cultural identities and received notions of selfhood, questioning in the process the notion of finality in translation. She thus uses translation as a tool to deflect the power of language, not only to reflect but also to construct reality. If Madhavikutty is Kamala Das in translation what she does in Ente Katha is to earn the right to "transgress from the trace of the other."

Kamala Das's self translation of the story of her life reveals a writer who is forced to mould herself and her story according to two contradictory sets of cultural and linguistic norms. Culture here becomes a category more of enunciation than representation. Bhabha's description of translation as imitation comes in handy here, as "Translation is also a way of imitating, but in a mischievous displacing sense - imitating on original in such a way that priority of the original is not reinforced but the very fact that it can be simulated, copied, transferred, transformed, made into a simulacrum and so on: the 'original' is never finished or complete in itself. The originary is always open to translation so that it can never be said to have a totalized prior moment of being or meaning an essence." For Kamala Das translation becomes a foundational activity where the unfinished original, both as self and text, is reworked and renegotiated in another culture and language. So fidelity is never a major concern with people like her who write from 'liminal' and 'hybrid' spaces. The neurosis of nostalgia that one finds in her autobiography is yet not the complete truth. For she is never really at home in Nalappat, often having to escape to Mumbai and then back to her ancestral home again. For an identity, carrying this trauma of dislocation, divided between the other tongue of English and the mother tongue of Malayalam, translation is an activity that best describes her being. 
Critics like Mary Jean Corbett argue that autobiography is a way of attaining both literary legitimacy and a desired subjectivity. But the problem is whether this desired subjectivity is different for a writer while writings in two different languages. The literary tradition of the autobiographical genre in Malayalam has been dominated solely by men, especially men like V.T. Bhattathirippadu \& E.M.S. Namboothippadu, who have played great roles in the public sphere in Kerala. For such great literary and social figures the autobiography was an unproblematic genre by which they could acquire a desired subjectivity as seekers/producers of knowledge necessary for social amelioration. Ente Katha challenges the gendered separation of the public sphere from the private by exposing the so-called domesticity of woman as a social construct. And yet again and again Madhavikutty apologizes or attempts to justify herself. For example she writes in Ente Katha

\begin{abstract}
"There are various reasons why I do not subscribe to the laws of morality prescribed by the society. The foundation of this morality is the mortal body. I believe that a supreme or salutary morality ought to be created in the immortal soul or if not, at least in the human mind... By telling lies, acting, cheating and hating many, I too could have covered myself in the blanket of society's pseudo morality and procured for myself a place of warmth and security underneath it... In a way writing such an autobiography truthfully, without hiding anything, is a striptease..." (p. 87-88).
\end{abstract}

These apologies and attempts to spiritualize the body are not to be found in My Story and betray an unconscious fear of social ostracisation associated with writing the female body. This register of anxieties, this culturally conditioned paranoia is more pronounced in Ente Katha, where Madhavikutty employs several such strategies of philosophizing and justifying the trauma of female sexual transgression even as she attempts to transgress the patriarchal norms of representing the female. Despite this which stands out in both versions of Das's story is the female body, as real, an essence 
which is unsymbolizable, an unrepresented, unrepresentable space that challenges the patriarchal text from the margins. What comes through is a quest to retrieve this body lost in translation in the symbolic language. Within the discourse of autobiographical writing Kamala Das uses the body as a space of difference, a space from where she could think femininity beyond the control of the phallic subject.

It is the marginalized semiotic aspect of Malayalam language that runs through Ente Katha. The poetry in My Story that is integrated into the text of Ente Katha makes it at times a nonrational discourse of the self which threatens the order of the symbolic language. Unlike in the male autobiographical tradition in Malayalam, Madhavikutty uses the irrational discourse of the semiotic to deconstruct women's marginalisation from the sociosymbolic contract. Yet it is important to note that such forms of subjectivity, which attempt to subvert dominant discourses are at all times dubbed neurotic and immoral and punished by society. VBC Nair says in an interview that Madhavikutty behaved like a 'street woman' when she stormed into his office alleging that he had twisted her writing to suit his purpose. The choice of epithets is highly significant and suggests the cultural salience's the word woman takes, offering an insight into society's negative attitude to woman and her body. The implication is that the female body should be cloistered at home; in the street it acquires the connotation of free availability. This about an eminent writer in Malayalam is indeed shocking. No wonder the writer felt compelled at some point in her life to say that she had written the autobiography at the behest of her husband for money he wanted, and that she was truly a 'pathivratha', obedient in her life to her husband. The very usage 'street-woman' by a man of some social standing is indicative of the male bias of the Malayalam language and its underlying cultural assumptions marked by the stamp of patriarchy. In such a culture the woman's body can only be seen as a tool to oppress her. Such a culture endorses masculinity as dominance and femininity as 
acquiescence to male domination, and sex as another act of conquest over the feudal holding of the female body. So the writer whose story reveals that it is the "discursive production of the nature of woman's bodies" that is "central to the reconstitution of social norms of femininity, the patriarchal subjection of women and their exclusion from most aspects of public life" is punished by the patriarchal power structures.

What Madhavikutty does in Ente Katha is a neat toppling over of the patriarchal ideological base of the Kerala society. By exposing the limits of its domestic contract, the compromises inherent to its social fabric, the pitfalls of its system of education and above all the complete resistance to feminist gender critique, she problematises the relation between the female self and society. All the personal lampooning and hatred that forced Madhavikutty to disclaim the truth of her story points to the fate of all women in the public sphere in Kerala who attempt to construct discursively the experience of sexuality of Malayalee women. Women's sexuality as a lexical gap in Malayalam literature and language echoes the dilemma of a culture still searching for ways to articulate the experience of womanhood. My Story/Ente Katha as the story of Malayalee women, has to be 'fictionalized' and made unauthentic to serve the purpose of all social and cultural agents paying allegiance to the symbolic powers. But together, through their open endedness and polysemy, they skillfully displace the masculine symbolic order, making us perceive the need to generate more discourses of the female self in order to reveal the other side of social history.

Mikhail Bakhtin points out that "Language is not a neutral medium that passes freely and easily into the private property of the speaker's intention, it is populated - over populated - with the intentions of others. Expropriating it, forcing it to submit to one's own intentions and accents, is a difficult and complicated process." Like Irigaray's impassioned plea for a woman-centered language, Madhavikutty's story has at its base the libidinal impulses of the 
female body narrated in a fluid language charged with feminine sexuality embodying all feminist resistances to patriarchal hegemonies of representation. Probably for the first time in Malayalam a woman attempts the 'ectriture feminine', rationalizing the irrational, moralizing the immoral and eroticising women's desire. Ente Katha in 1972 seems to be an antecedent to Irigaray's "When Our Lips Speak Together," originally published in 1977. It almost reads like a forerunner to the essay, where Madhavikutty indeed begins a 'different' story in a language different from men's, without letting 'convention' and 'habit' to distract her. Ente Katha breaks the circle of conventional habit, the 'circularities' of male exchanges, knowledge and desire, by expressing multiplicities and speaking 'improperly'. Kamala Das cannot translate Madhavikutty for each is 'several voices', 'several ways of speaking,' yet never separable from the other. Like Irigaray they assert that there is no 'possible evil' in women's sexual pleasure, the only fault being stripping a woman of her 'openness' and 'marking her with signs of possession'. But women too should refuse to 'submit' to male 'reasoning', refuse to feel 'guilty', for it is a male strategy to make women feel 'guilty'. Eliciting Madhavikutty's confession that Ente Katha was written with the sole intention of making money, society finally succeeded in the strategy calculated to make her guilty for her story. Yet in another recent interview given to Shobha Warrior for Rediff she reiterates that her autobiography was no fantasy. Kamala Das/Madhavikutty, in writing/translating her story, thus leaves 'definitiveness' to the 'undecided', being what she becomes, 'without clinging' to what she 'might have been' trusting only the 'certainty' of the body. 


\section{REFERENCES}

Madhavikutty (1989) Ente Katha, Kottayam: DC Books.

Kamala Das (1976) My Story, New Delhi: Sterling.

Linda Anderson (1986) At the Threshold of the Self: Women and Autobiography in Moira Moneith Sussex (ed.), Women's Writing: A Challenge to Theory, Harvester Press.

James Olney, (ed), (1980) Some Versions of Memory/Some Versions of Bios: the Ontology, Autobiography: Essays Theoretical and Critical Princeton University Press.

P.P. Raveendran (1998). In Conversation: Kamala Das, Malayalam Literary Survey (Vol.20, No.4 October - December).

------ (2004) Interview with V.B.C. Nair. Pachamalayalam (Vol.2, No.3), March .

P.P. Raveendran. In Conversation: Kamala Das, Malayalam Literary Survey.

M. Foucault (1972) The Archaeology of Knowledge, London: Tavistock.

Braj K. Kachru (2000) The Alchemy of English in Lucy Burke, Tony Crawley and Alan Girvin, (eds.), The Routledge Language and Cultural Theory Reader, London: Routledge.

Marie-Francoise Chanfrault-Duchet (2000) Textualisation of the Self in the Life-Story in Tess Cosslett, Celia Lury and Penny Summerfield (eds), Feminism and Autobiography: Texts, Theories, Methods, London: Routledge. 
Ruth Mc Elroy, Bringing it Home: Autobiography and Contradiction in Feminism and Autobiography: Texts, Theories, Methods.

Gayatri Chakravorty Spivak (1993) The Politics of Translation in The Teaching Machine, New York: Routledge.

Homi K. Bhabha (1990) The Third Space in J. Rutherford (ed), Identity, Community, Culture, Difference, London: Lawrence and Vishart.

Mary Jean Corbett (1992) Representing Femininity, Oxford: Oxford University Press.

Kamala Suraiya (2002) Mathavum Premavum in Bhashaposhini, Annual Issuie.

Chris Weedon (1987) Feminist Practice and Poststructuralist Theory (Cambridge: Blackwell.

Mikhail Bakhtin (2000) Unitary Language in Lucy Burke, Tony Crawley and Alan Girvin (eds), The Routledge Language and Cultural Theory Reader (London: Routledge.

Luce Irigaray, When Our Lips Speak Together in The Routledge Language and Cultural Theory Reader.

Shobha Warrior. Interview. Rediff on the Net. Online. Available: http://www.rediff.com/news/1996/3107adas.htm 
